the hope that he might be enabled to undertake further researches, being of the opinion that there is no field of archaeological inquiry which offers greater prospects for the future.

\title{
Exposition au Musée du Trocadéro par M. Labouret.
}

Au cours de la mission scientifique qu'il a accomplie dernièrement en Afrique Occidentale, M. Labouret ne s'est pas borné à recueillir les observations scientifiques et directes sur les sociétés négro-africaines et sur les droits fonciers, il a collectionné de très nombreux objets concernant les diverses activités des communautés qu'il a visitées. Il a pu obtenir en outre un assez grand nombre de pièces relatives au culte et aux manifestations des sociétés dites secrètes, en particulier de celle du Simo.

Ces différents objets, de taille diverse, au nombre de plus de 500, comportant depuis des instruments culinaires jusqu'à des masques sacrés haut de plus d'un mètre cinquante ont été offerts au Trocadéro. Le Musée d'Ethnographie et le Muséum National d'Histoire Naturelle dont dépend le Musée, ont jugé le don tellement important qu'ils ont décidé d'en faire une exposition ouverte au public du 28 avril au 28 mai.

Cette manifestation a eu le plus grand succès en faisant connaître l'Institut et son œuvre. Flle a été annoncée dans tous les journaux français et dans quelques organes de la presse anglo-saxonne continentale. L'Exposition a été ouverte par M. Albert Sarraut, Ministre des Colonies. Il s'est fait expliquer longuement les méthodes de travail et de recherches employées pour étudier les sociétés et les droits fonciers. Il a été vivement frappé par les procédés utilisés pour recenser les familles, observer les genres de vie, le travail, la collaboration des communautés. Le Ministre s'est arrêté dans la salle réservée aux masques Simo et il a admiré l'effigie monumentale de Nimba, représentation de la fertilité et de la fécondité, qui se dresse au milieu.

\section{Exposition du Livre Colonial.}

Une Exposition du Livre Colonial a été organisée à Paris du 29 mai au 3 juin. Elle a eu lieu au siège de l'Agence Économique du Gouvernement Général de l'Indochine, rue La Boëtie à Paris. M. Albert Lebrun, Président de la République, et M. Albert Sarraut, Ministre des Colonies, avaient tenu à l'inaugurer en personne.

Grâce à l'amabilité du Comité Directeur, un stand avait été réservé aux publications de l'Institut, qui ont été admirées et consultées par de nombreuses personnes.

\section{The Linguistic Situation in the Western parts of the Niger Delta.}

Mr. Welch's communication on this subject in the April number of Africa (p. 220-222) is of great interest to those acquainted with this part of Nigeria 
and it is good to hear that he is producing an account of these local tribes, which, though known to Europeans for some hundreds of years, have never yet been exhaustively studied.

So far as linguistics are concerned, it might be pointed out that Sobo, which is the anglicized form of Uzobo, and Isoko (or Igabo) are two dialects of a branch of the Edo language, which includes also Bini, Esa, and Kukuruku, and has been thoroughly dealt with in Mr. Northcote Thomas's books.

Ishekiri (or Itshekiri)-better known under its conventionalized name of Jekri-is a dialect of Yoruba. Ijo, as Mr. Welch observes, is 'quite distinct' -and is, in fact, very different from all other Nigerian languages.

The only classification of Southern Nigerian tribes, which has, so far as I know, yet been carried out, is that contained in my Peoples of Southern Nigeria, particularly vol. IV, ch. 3. For want of a better criterion this was mainly based on language, but fortunately it appears from the anthropometrical investigation, on which I am now engaged, that few modifications will be necessary.

It seems however that the Eastern Ijo (or Kalabari) are quite distinct physically from the western section who dwell near the Edo-speaking peoples, with whom they have much in common. In this latter region there has evidently been a considerable Sobo admixture, while there is probably some truth in the local tradition of a Bini settlement near Brass, referred to on page 318 of vol I of The Peoples of Southern Nigeria.

On the other hand, the physical characters of the Yoruba and Edo are sufficiently similar to make it difficult to determine, until all the figures have been worked out, the exact position of the Jekri between the two groups, but there is no doubt that these have so intermarried with their Sobo neighbours that in some respects they are nearer to them than to the Yoruba. Traditions of their origin from the last-named tribe are given on p. 317 of the above-mentioned book.

\section{(Communicated by P. Amaury Talbot.)}

\section{Prize Competition for Books in African Languages, 1934.}

Duala, Shambala and Swina have been selected as the three languages in which books written by Africans in African languages may be entered for competition next year.

The regulations will be the same as in previous years, and leaflets giving full details are available. Manuscripts must reach the offices of the Institute by October Ist, 1934 .

The Council will greatly appreciate any assistance that members can give in making this competition known as widely as possible among Africans likely to be interested. 